\title{
Christiaan Maurits van den Heever.
}

27 Februarie 1902—8 Julie 1957.

Maar kan die hart ooit van sy droom genees, en Lucifer na sy ontbinding keer, om te vermolm en dromeloos te wees met geen herinnering aan sy Oorsprong meer?

Met die dood van C. M. van den Heever het ons 'n figuur ontval wat ' $n$ betekenisvolle rol in ons literêre lewe en in ons volkslewe gespeel het.

As ek my 'n oomblik wil besin op sy betekenis, dan dink ek nie aan die gevierde literator en kultuurman van die laaste jare nie. My gedagtes gaan terug na die skraal jong man van 1926, beskeie en sjarmant, geesdriftige bewonderaar van die letterkunde, veral van die Dietse, wat met innige vreugde 'n mooi vers van Bloem so stilweg vir homself kon opsê en wat in Die Volksblad gevoelige kritieke geskryf het. Hy was destyds aan hierdie koerant en aan Die Landbouweekblad verbonde. Tegelykertyd het hy gestudeer en sy eerste skugtere literêre proewe die lig laat sien.

Sy Stemmingsure (1926) is nieteensta:ande al die jeuggebreke, blyke van literêre onmag nog en naklanke van ander digters, tog reeds die stemvurk van sy poësie. Hier is in die sagneuriënde sang van sy verglyende vers reeds die eenselwige mymeraar oor dood, verganklikheid en verlede in 'n geáempte stemmingsfeer van skemering, maanlig en herfs aan die woord en tref hy ons meermale deur verse van suiwere vormgewing :

Nog ween die konsertienastem en bewe die wysie, waarin verlange lewe vol ou weemoed en herin'ringspyn. Dit is weer stil! en in die stilte skryn die groot verlange na die ewige sterre; en luister! soos 'n stemmetjie van verre klaag die ou spruitjie in donker-en verdwyn.

In 1927 verskyn sy novelle Op die Plaas, in wese verwant aan hierdie kuns: ook hier die stemmingslewe van 'n eenselwige dromer te midde van die met fyn sintuiglikheid waargenome natuur. 
In 1928 gaan Van den Heever vir verdere studie na Utrecht, Nederland, waar hy die doktoraaleksamen aflê onder prof. C. G. N. de Vooys. $\mathrm{Na}$ sy terugkoms promoveer hy op 'n proefskrif oor Totius as Digter. Sy betekenis vir die Afrikaanse Letterkunde. Die onderwerpskeuse was nie willekeurig nie-as droomversonke mymeraar oor die misterie van dood en verganglikheid het hy duidelike affiniteit met die ouer digter en ondergaan ook sy invloed.

Ondertussen het sy tweede digbundel verskyn, Die Nuwe Boord (1928), ook nog kennelik jeugwerk, maar dit bevestig die beeld van sy digterskap wat in die eerste bundel deurskemer, en bring naas veel wat onryp en onsuiwer is, reeds enkele voldrae gedigte waarin die stemming verdiep tot lewsnsdroom. Ek dink hier veral aan daardie wonder van musikaal-ritmiese beelding wat so simboliek groei:

Die wêreld is hier wyd omkrans met bome, en 'n sag-rooi glans gloei nou deur hul aan westertrans.

Hul staan so stil--so yl en kaal, die peinsers, as die son gaan daal en sterre om hul hoof kom straal.

'n Valk klap bang sy vlerke oor die stokou takke - gou tog hoor hy stilte, raak daarin verloor.

Omwaas word hulle, blouig-wit, met dunne newels, totdat dit kompleet nou lyk of grysaards bid.

Die bome is al oud en kaal, die newels kom oor hulle daal, maar bo-oor bly die sterre straal.

In dieselfde jaar verskyn sy roman Langs die grootpad, nog opsetlik in sy strewe na simboliek, nog romantiekerig, maar reeds met goeie skildering van die plaaslewe en die natuur en van gemoedstoestande. Dieselfde geld van Droogte, wat goeie sintuiglike waarneming van die natuur gee, die worsteling van die boer met die meedoënlose natuur en met inherente swakheid, waardeur hy ondergaan, geslaagde tekening van tipes cn die onvergetelike skrynende humor in die figuur van $\mathrm{Ou}$ Datie. 
In 1932 verskyn 'n werk van besondere betekenis, nie alleen in Van den Heever se ontwikkelingsgang nie maar ook in die van ons digkuns, sy bundel Deining, later verryk met 'n aantal belangrike gedigte uit dieselfảe grondstemming gegroei. Waar enkele kritici reeds by die verskyning van „Stemmingsure” ell „Die Nuwe Boord” die nuwe opgemerk het, wora vandag erken dat „Deining” „met sy verheerliking van die kunstenaar, die nuwe sintuiglikheid, beluistering van eie sielelewe, groter ekspressiwiteit en 'n wyer en soepeler versbeweging die eerste bundel van Dertig is" (Opperman). Dit bly vir my die hoogtepunt van sy digterskap, al sal Die Aardse Vlam verdere verfyning van sy vers bring, maar ook veryling, en Latere Gedigte nuwe konflikte en motiewe, maar ook 'n vermindering van spanning wat tot vormloosheid lei-dikwels laat hy hom só primêr deur die eentonige mymermusiek in hierdie twyfelgedigte lei dat die konkrete beeld, wat nouliks 'n rol gespeel het in die ontstaan van die gedig, vervaag.

Om te besef watter subtiele, tot simboliek uitgroeiende stemmingsbeelding in soepele versbeweging Van den Heever gee in „Deining”, hoef ons slegs „Voëls in die Skemering" weer 'n keer te lees:

Voëlgeklepper in die skemer oor buigende riet,

en soos vlae wit sneeu uit die ruimte, die hemel, daal hulle neer, daal soos 'n droom.

En die nag doem aan oor die bulte, verrysend uit rooi van sterwende lig, en die wind ween sag in die riet ween sy slaperige lied van die sterwende dag en die nag.

En skemerig-wit

in die duister sit die voëls soos bannelinge

eensaam

na die weegeroep

van die wind en luister. 
$\mathrm{Na}$,Deining” sal die leiding in die digkuns oorgaan na die dinamieser Van Wyk Louw, by wie nie die stemmingslewe nie maar die metafisiese denke tegelykertyd die bron en vorm van sy estetiese ontroering en verbeelding is. Daardeur het die figuur van Van den Heever enigsins op die agtergrond geraak en word die estetiese waarde en die literêr-historiese betekenis van „Deining” nie genoegsaam besef nie.

Nieteenstaande sy groot vrugbaarheid as skrywer van romans en verhale is sy belangrikste bydrae tot ons letterkunde sy poësie. Wat nie wil sê dat hy nie ook 'n waardevolle bydrae tot die prosa gelewer het nie. Wel merk ons daarin 'n fnuikende skepsis op, styg hy dikwels te weinig uit tot die hoër, universele kritiek van wie homself insluitdink slegs aan Kromburg. Ook het hy, veral later, te haastig en te maklik geskrywe, sodat hierdie romans geen verbete ontworsteling van die waarheid aan die lewe is nie. Maar die novelle Somer en die roman Laat Vrugte, met sy strakker konsepsie en beelding, behoort tot die beste wat ons prosakuns voortgebring het, en ons sal altyd die ontroering bly ondergaan van sy beste kortverhale met hulle fyn innerlike spanning en humor, bekoor word deur menige bladsy beeldende prosa, geboei word deur goed getekende tipes, veral in sy plaasromans.

Met die verdere groei van ons letterkunde en met die ontgroeiing van komende generasies aan die tydsfaktore in sy werk sal ook Van den Heever se kuns 'n herwaardering ondergaan, maar ek is daarvan oortuig dat ook die later geslagte daarin sy eie woorde bewaarheid sal bly vind:

Want teen die diepte van die tye staan dié mens deur wie oneindighede gaan.

G. DEKKER. 